\title{
Macrocyclic Chelates Bridged by a Diaza-Crown Ether: Towards Multinuclear Bimodal Molecular Imaging Probes
}

\author{
Gaoji Wang ${ }^{1}$ and Goran Angelovski ${ }^{1,2, *}$ \\ 1 MR Neuroimaging Agents, Max Planck Institute for Biological Cybernetics, Max-Planck-Ring 11, \\ 72076 Tübingen, Germany; gaoji.wang@tuebingen.mpg.de \\ 2 Lab of Molecular and Cellular Neuroimaging, International Center for Primate Brain Research (ICPBR), \\ Center for Excellence in Brain Science and Intelligence Technology (CEBSIT), Chinese Academy of \\ Science (CAS), Shanghai 200031, China \\ * Correspondence: goran.angelovski@tuebingen.mpg.de
}

Academic Editor: Zoltan Kovacs

Received: 29 September 2020; Accepted: 27 October 2020; Published: 29 October 2020

\begin{abstract}
Bridged polymacrocyclic ligands featured by structurally different cages offer the possibility of coordinating multiple trivalent lanthanide ions, giving rise to the exploitation of their different physicochemical properties, e.g., multimodal detection for molecular imaging purposes. Intrigued by the complementary properties of optical and MR-based image capturing modalities, we report the synthesis and characterization of the polymetallic $\mathrm{Ln}$ (III)-based chelate comprised of two DOTA-amide-based ligands (DOTA-1,4,7,10-tetraazacyclododecane-1,4,7,10-tetraacetic acid) bridged via 1,10-diaza-18-crown-6 (DA18C6) motif. The DOTA-amide moieties and the DA18C6 were used to chelate two $\mathrm{Eu}(\mathrm{III})$ ions and one $\mathrm{Tb}(\mathrm{III})$ ion, respectively, resulting in a multinuclear heterometallic complex $\mathbf{E u}_{2} \mathbf{L T b}$. The bimetallic complex without $\mathrm{Tb}(\mathrm{III}), \mathbf{E u}_{2} \mathbf{L}$, displayed a strong paramagnetic chemical exchange saturation transfer (paraCEST) effect. Notably, the luminescence spectra of $\mathbf{E} \mathbf{u}_{2} \mathbf{L T} \mathbf{b}$ featured mixed emission including the characteristic bands of $\mathrm{Eu}(\mathrm{III})$ and $\mathrm{Tb}(\mathrm{III})$. The advantageous features of the complex $\mathbf{E u}_{2} \mathbf{L T b}$ opens new possibilities for the future design of bimodal probes and their potential applicability in CEST MR and optical imaging.
\end{abstract}

Keywords: diaza-crown ether; hetero-multinuclear complexes; lanthanide; luminescence; macrocyclic; paraCEST; water exchange

\section{Introduction}

In modern medicine, magnetic resonance imaging (MRI) is recognized as the method of choice for non-radiative and non-invasive imaging of soft body tissues [1-3]. Conventional MRI exploits the magnetic properties of water proton's spins to generate signal. However, it suffers from intrinsic insensitivity, which often requires the administration of contrast agents (CAs). Specifically, these mainly paramagnetic Ln(III)-based complexes improve specificity of the MRI scans through various contrast-generating mechanisms [3]. One of the recently introduced MRI strategies is based on the chemical exchange saturation transfer (CEST) effect, which possesses specific advantages over the conventional $T_{1}$-weighted MRI. Namely, the CEST MRI enables generation of the signal at will by using selected radiofrequency (RF) pre-saturation pulses, thus providing improved specificity in these MRI studies due to the absence of permanent background signal originating from the CEST agent [4,5]. The principle of CEST detection is based on the selective saturation of the pool of protons that are in slow to intermediate exchange rate on the NMR time-scale, with bulk water pool. Subsequently, the chemical exchange of the pre-saturated CEST proton pool with the 
water protons reduces the intensity of the MR signal at the frequency of the bulk water protons. The general requirement for successful CEST is that the frequency difference between the two pools of protons $(\Delta \omega)$ is greater than the corresponding exchange rate $\left(k_{\mathrm{ex}}\right)$ [6]. Moreover, the paramagnetic lanthanide(III) ions, such as $\mathrm{Eu}(\mathrm{III}), \mathrm{Tb}(\mathrm{III})$ or $\mathrm{Yb}$ (III), are known to induce chemical shifts (and hence $\Delta \omega$ ), which makes them perfect candidates for paramagnetic CEST (paraCEST) CAs [7-9]. As a general rule, the CEST effect is induced either by the exchangeable proton of the ligand or by the water molecule coordinated to Ln(III). Typically, Ln(III) complexes based on DOTAM (DOTA-tetraamide, DOTA-1,4,7,10-tetraazacyclododecane-1,4,7,10-tetraacetic acid) are characterized by an exchange rate suitable for CEST imaging [6]. Although the thermodynamic stability of the Ln(III)-DOTA-tetraamide complexes is considerably lower than that of the tetracarboxylate analogues, their kinetic inertness is extremely high, which makes them good candidates for potential in vivo applications [3,10-12].

Furthermore, $\mathrm{Ln}(\mathrm{III})$ ions, especially $\mathrm{Eu}(\mathrm{III})$ and $\mathrm{Tb}(\mathrm{III})$, have often been employed for optical sensing owing to their specific sharp line-like emission bands and long lifetimes, often being in the milliseconds range [13]. These features allow implementation of the time-gated techniques to increase the signal-to-noise ratio (SNR). Most importantly, lanthanide luminescence has large Stokes shifts (>200 nm) when compared to typical organic fluorescence compounds. Such unique photophysical properties circumvent the autofluorescence, as well as the light scattering from backgrounds of the biological samples, such as cell cultures or tissues [14]. Thus, besides suitable properties for optical imaging, complexes comprised of two different Ln(III) ions might provide properties suitable for dual-modal imaging, enabling the design of dual- and multi-modal probes [15-21].

In this work, we set out to investigate the possibility of developing a dual-modal agent that is suitable for CEST MR and optical imaging (Chart 1). We designed a molecule that consisted of two DOTAM-Gly macrocyclic moieties and a DA18C6 (DA18C6- 1,10-diaza-18-crown-6) azacrown moiety, intended for chelation of two different paramagnetic and luminescent Ln(III) ions. The DOTAM-Gly accommodated two Eu(III), giving rise to strong paraCEST signal of the generated dinuclear complex. The interaction of $\mathrm{Tb}$ (III) with the azacrown moiety resulted in the increase of the Tb-centered luminescence emission, showing the advantageous properties of the prepared multinuclear heterometallic complex as a potential dual-modal imaging probe.
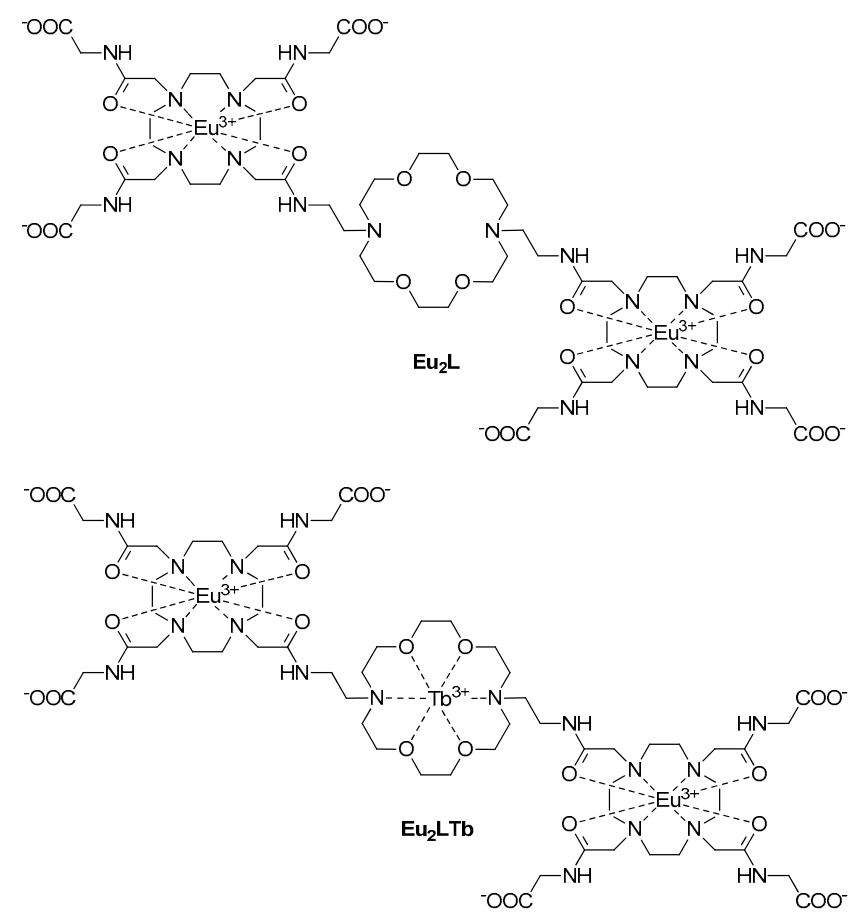

Chart 1. The chemical structures of $\mathbf{E u}_{2} \mathbf{L}$ and $\mathbf{E} \mathbf{u}_{2} \mathbf{L T b}$ investigated in this work. 


\section{Results and Discussion}

\subsection{Synthesis of Complexes $E u_{2} L$ and $E u_{2} L T b$}

The desired trismacrocyclic ligand was synthesized in a stepwise manner, using glycine ethyl ester hydrochloride, bromoacetyl bromide, 2-bromoethylamine hydrogen bromide and benzyl chloroformate as starting compounds (Scheme 1). In the first step, the cyclic polyamine 1 was alkylated with three equiv. of the bromide 2 to provide the macrocycle 3 . Hydrogenation of 3 catalyzed by Pd/C in DMF afforded the acid 4 in high yield. In the second, azacrown fragment 7 was prepared in a three-step procedure. The commercially available 2-bromoethylamine hydrogen bromide was reacted with benzyl chloroformate to yield Cbz-protected amine 5 [22]. Then, two equiv. of 5 were reacted with 1,10-iaza-18-crown-6 to acquire azacrown dicarbamate 6 , which was then subjected to the catalytic deprotection of $\mathrm{Cbz}$ groups by hydrogenation in the presence of $\mathrm{Pd} / \mathrm{C}$ in ethanol to afford the diamine 7. Coupling of two equiv. of the acid 4 with the diamine 7 resulted in the thismacrocyclic precursor 8. Finally, the base hydrolysis of $\mathbf{8}$ was achieved with $\mathrm{LiOH}$ to give the final ligand $\mathbf{H}_{6} \mathbf{L}$. The obtained compounds were characterized by ${ }^{1} \mathrm{H} /{ }^{13} \mathrm{C}-\mathrm{NMR}$ and mass spectrometry. The bimetallic complex Eu $\mathbf{u}_{2} \mathbf{L}$ was prepared by treating the final ligand $\mathbf{H}_{6} \mathbf{L}$ with $\mathrm{EuCl}_{3} \cdot 6 \mathrm{H}_{2} \mathrm{O}$ in water, while maintaining the $\mathrm{pH}$ at $\sim 7$. Subsequently, complex $\mathbf{E u}_{2} \mathbf{L T b}$ was prepared by treating $\mathbf{E u}_{2} \mathbf{L}$ with one equiv. of $\mathrm{TbCl}_{3}$ aqueous solution and was characterized by LC-MS spectrometry.

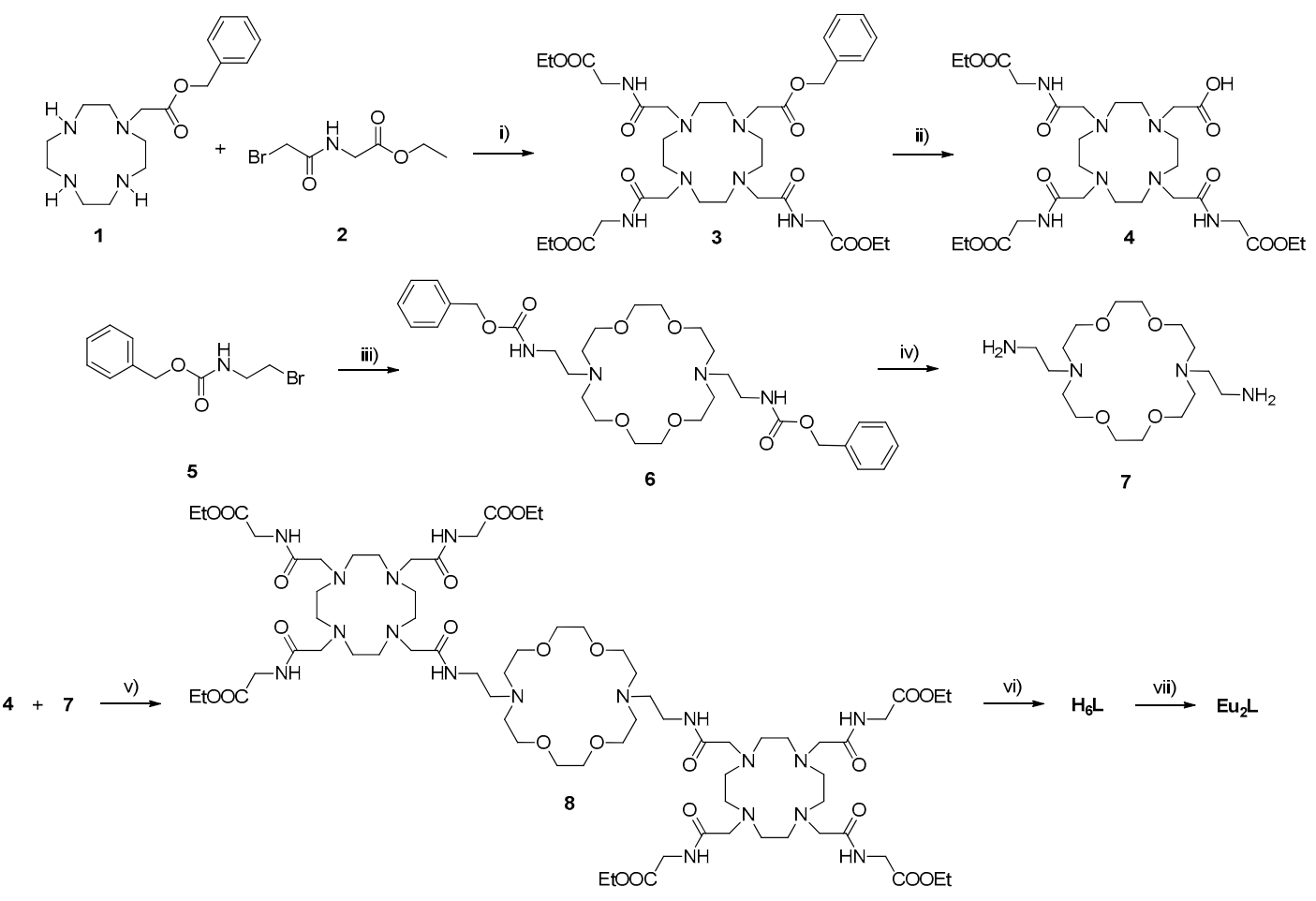

Scheme 1. Synthesis scheme of complex $\mathrm{Eu}_{2}$ L. Reagents and conditions: (i) $\mathrm{Na}_{2} \mathrm{CO}_{3}, \mathrm{DCM}$, r.t. 12 h; (ii) $\mathrm{H}_{2} / \mathrm{Pt}$, DMF, r.t., 12 h; (iii) $\mathrm{MeCN}_{2} \mathrm{Cs}_{2} \mathrm{CO}_{3}, 65^{\circ} \mathrm{C}, 4.5$ h; (iv) $\mathrm{H}_{2} / \mathrm{Pt}$, EtOH, r.t., 4 h; (v) HATU, DMF, r.t., 6 h; (vi) $\mathrm{LiOH}, \mathrm{MeOH}$, r.t., $12 \mathrm{~h}$; (vii) $\mathrm{EuCl}_{3} \cdot 6 \mathrm{H}_{2} \mathrm{O} / \mathrm{H}_{2} \mathrm{O}, 50{ }^{\circ} \mathrm{C}, 12 \mathrm{~h}$.

\subsection{CEST Effect Measurements of $\mathbf{E} \boldsymbol{u}_{2} \mathbf{L}$}

Given that the EuDOTAM-Gly complex is a well-studied paraCEST agent, the CEST properties of its structural analogue $\mathbf{E} \mathbf{u}_{2} \mathbf{L}$ were investigated in detail and compared accordingly [23-25]. The CEST

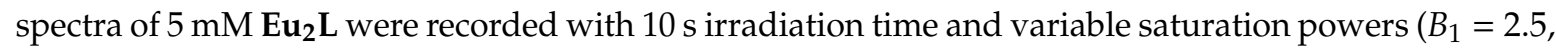
$5,10,15,20,25$ and $30 \mu \mathrm{T}$ ) at $25^{\circ} \mathrm{C}$ and pH 7.4 (Figure 1). The CEST signal resonating at $\sim 50 \mathrm{ppm}$ was observed for $\mathbf{E u}_{2} \mathbf{L}$, corresponding to the proton exchange between $\mathrm{Eu}(\mathrm{III})$-bound water and the 
bulk water molecules. The CEST effect depends on the saturation power variation [26], resulting in a CEST effect increase from $\sim 5 \%$ to $\sim 60 \%$ for the increase in saturation power from $5 \mu \mathrm{T}$ to $30 \mu \mathrm{T}$, respectively (Figures S1 and S2, Supplementary Materials).

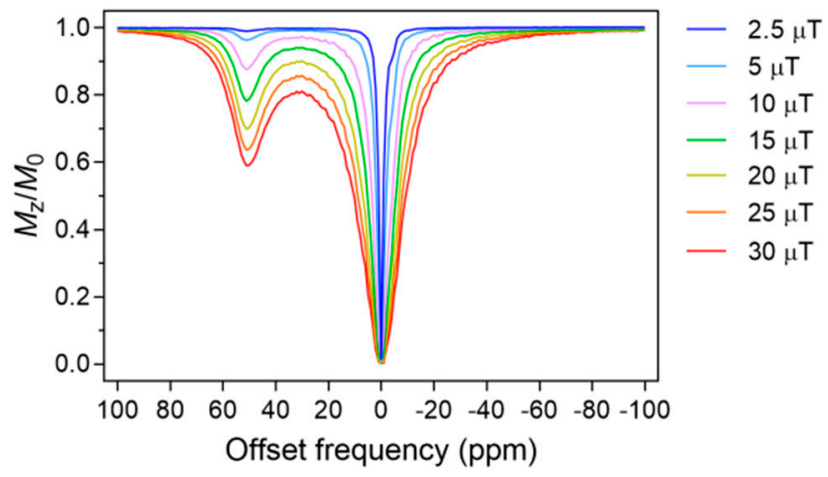

Figure 1. The CEST spectra of the complex $\mathbf{E u}_{2} \mathbf{L}(5 \mathrm{mM}$, irradiation time $10 \mathrm{~s}$, in $50 \mathrm{mM}$ HEPES with $\mathrm{pH} 7.4,25^{\circ} \mathrm{C}$ ) recorded at different $B_{1}$.

Both the chemical shift of the inner-sphere bound water and the saturation efficiency of the bulk water were affected by temperature (Figure 2a). The chemical shift of the bound water pool shifted upfield with an increase in temperature (chemical shift from $57 \mathrm{ppm}$ at $10{ }^{\circ} \mathrm{C}$ to 45 ppm at $40{ }^{\circ} \mathrm{C}$ ). The fitting results suggested a linear-dependence between the chemical shift of the bound-water protons with temperature (Figure $2 b$ ). The observed sensitivity of the chemical shift to temperature is $0.4 \mathrm{ppm} /{ }^{\circ} \mathrm{C}$, which is similar to that of EuDOTAM-Gly [27]. This suggested that $\mathbf{E} \mathbf{u}_{2} \mathbf{L}$ could be used to measure temperature distribution in a living subject. The peak width of both bulk and bound water also increased with temperature (Figure 2a), owing to more rapid exchange.

a)

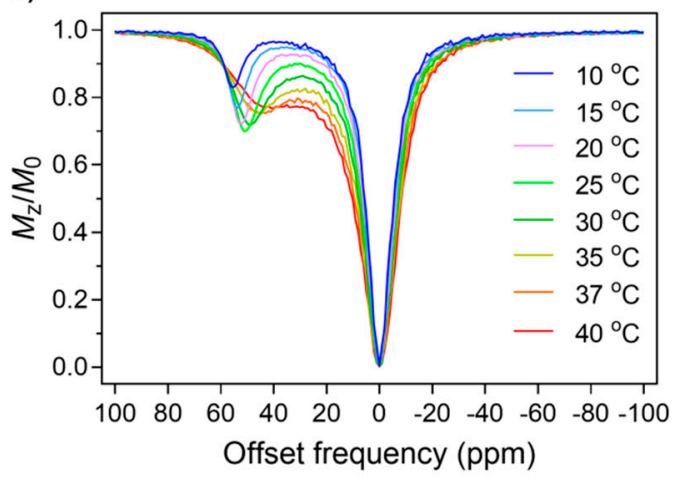

b)

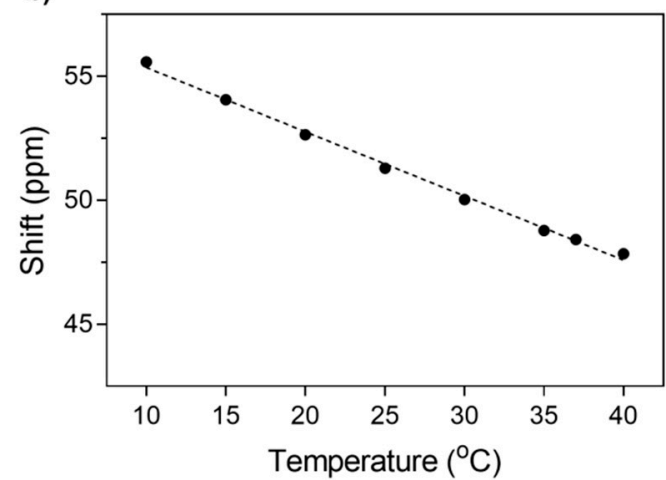

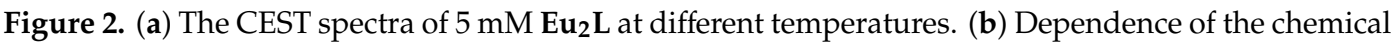
shift of the bound water protons on temperature $\left(\mathrm{pH}=7.4, B_{0}=7 \mathrm{~T}\right.$, saturation power $B_{1}=20 \mu \mathrm{T}$, irradiation time $10 \mathrm{~s})$.

The water exchange rates, $k_{\mathrm{ex}}$, at different temperatures, were extracted using the quantitative CEST (qCEST) method [28]. In short, the Bloch-McConnell (BM) equations were used for fitting the experimental data, assuming a three-pool fitting model (bulk water, amide protons and the paraCEST pool). The $k_{\mathrm{ex}}$ values are progressively increasing as the temperature gets higher (Table 1 ). At $25^{\circ} \mathrm{C}$, the BM fitting three-pool model revealed the exchange rate of around $10 \mathrm{kHz}$, which corresponds to the bound-water lifetime $\left(\tau_{M}\right)$ of around $100 \mu$ s; this value is comparable to $\tau_{M}$ reported for EuDOTAM-Gly at same temperature [29]. With such properties displayed, the bismacrocyclic $\mathbf{E} \mathbf{u}_{2} \mathbf{L}$ shows very good perspectives for future use as the paraCEST agent. Namely, owing to its bimetallic nature, Eu $\mathbf{u}_{2} \mathbf{L}$ can 
produce the CEST signal almost twice stronger than EuDOTAM-Gly, for the same amount of the probe, while potentially having even longer retention time in tissue due to its larger size.

Table 1. The $k_{e x}$ values of bound water molecule $\left(5 \mathrm{mM}\right.$ complex $\left.\mathbf{E u}_{2} \mathbf{L}\right)$ using the quantitative CEST (qCEST) method at different temperatures. Each temperature experiment was recorded at $\mathrm{pH} 7.4$, with irradiation time of $10 \mathrm{~s}$ and different $B_{1}(2.5,5,10,15,20,25$ and $30 \mu \mathrm{T})$.

\begin{tabular}{ccccccccc}
\hline Temp. $/{ }^{\circ} \mathbf{C}$ & $\mathbf{1 0}$ & $\mathbf{1 5}$ & $\mathbf{2 0}$ & $\mathbf{2 5}$ & $\mathbf{3 0}$ & $\mathbf{3 5}$ & $\mathbf{3 7}$ & $\mathbf{4 0}$ \\
\hline$k_{\text {ex }} / \mathrm{kHz}$ & $3.8 \pm 0.4$ & $4.7 \pm 0.3$ & $6.3 \pm 0.3$ & $8.9 \pm 0.3$ & $12.9 \pm 0.4$ & $18.6 \pm 0.5$ & $21.5 \pm 0.5$ & $26.7 \pm 0.6$ \\
\hline
\end{tabular}

\subsection{Photophysical Characterization of $E u_{2} L T b$}

The DA18C6 moiety in complex $\mathbf{E u}_{2} \mathbf{L}$ is also a chelator, albeit capable of binding another type of Ln(III) ion weakly [30,31]. To this end, we investigated the interaction of the $\mathbf{E u}_{2} \mathbf{L}$ with $\mathrm{Tb}$ (III) and the photophysical properties of the resulting hetero-trinuclear lanthanide complex Eu $\mathbf{u}_{2} \mathbf{L T b}$ (Figure S3, Supplementary Materials). This complex displayed mixed emission spectra in solution, which included characteristic peaks of both terbium $\left({ }^{5} \mathrm{D}_{4} \rightarrow{ }^{7} \mathrm{~F}_{J}\right)$ and europium $\left({ }^{5} \mathrm{D}_{0} \rightarrow{ }^{7} \mathrm{~F}_{J}\right)$ ions [32]. Specifically, the emission spectra of $\mathbf{E} \mathbf{u}_{2} \mathbf{L T b}$ were recorded using excitation wavelengths ranging from $225 \mathrm{~nm}$ to $395 \mathrm{~nm}$ (Figure 3). The emission excited at $225 \mathrm{~nm}$ exhibited the spectrum with four characteristic signals in the visible region at $494 \mathrm{~nm}\left({ }^{5} \mathrm{D}_{4} \rightarrow{ }^{7} \mathrm{~F}_{6}\right), 545 \mathrm{~nm}\left({ }^{5} \mathrm{D}_{4} \rightarrow{ }^{7} \mathrm{~F}_{5}\right), 588 \mathrm{~nm}\left({ }^{5} \mathrm{D}_{4} \rightarrow{ }^{7} \mathrm{~F}_{4}\right)$, and $625 \mathrm{~nm}$ $\left({ }^{5} \mathrm{D}_{4} \rightarrow{ }^{7} \mathrm{~F}_{3}\right)$, originating from the $\mathrm{Tb}(\mathrm{III})$ ion $[33,34]$. Concurrently, the emission excited at $395 \mathrm{~nm}$ resulted in the spectrum having four characteristic peaks in the visible region at $598 \mathrm{~nm}, 616 \mathrm{~nm}$, $656 \mathrm{~nm}$, and $702 \mathrm{~nm}$, arising from the ${ }^{5} \mathrm{D}_{0} \rightarrow{ }^{7} \mathrm{~F}_{J}(\mathrm{~J}=1,2,3,4)$ transitions of the Eu(III) ion, respectively. Additionally, the spectra excited at $265 \mathrm{~nm}, 283 \mathrm{~nm}$ and $305 \mathrm{~nm}$ showed the combined emission peaks from both $\mathrm{Eu}(\mathrm{III})\left({ }^{5} \mathrm{D}_{0} \rightarrow{ }^{7} \mathrm{~F}_{J}\right)$ and $\mathrm{Tb}(\mathrm{III})\left({ }^{5} \mathrm{D}_{4} \rightarrow{ }^{7} \mathrm{~F}_{J}\right)$ transitions.

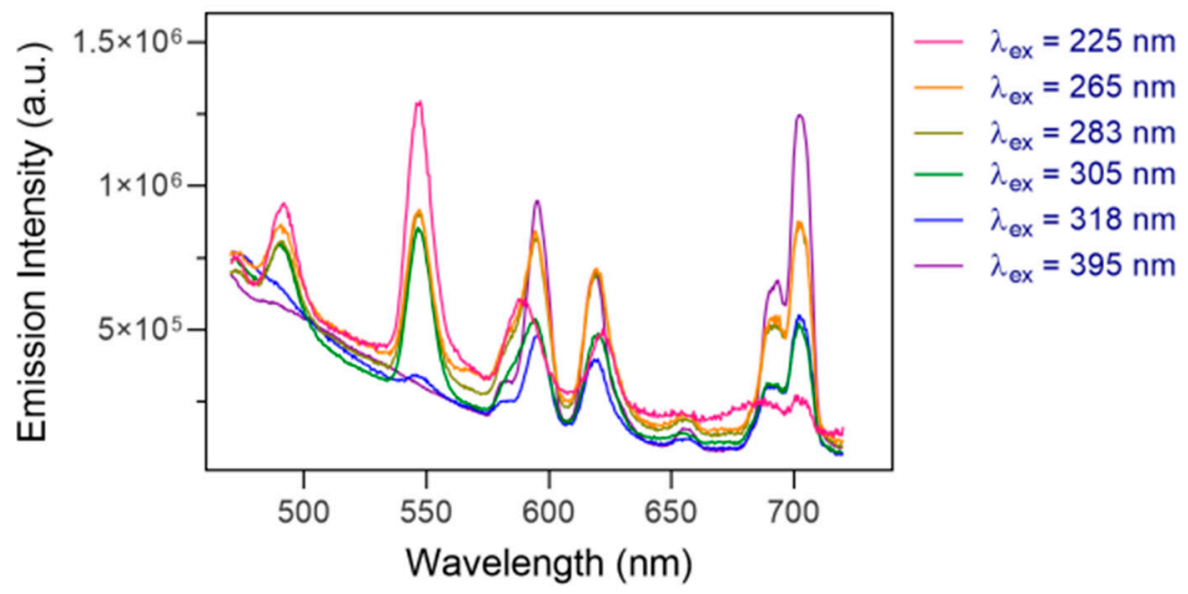

Figure 3. Luminescence spectra of $0.2 \mathrm{mM}$ complex $\mathbf{E u}_{2} \mathbf{L T b}$ at $25^{\circ} \mathrm{C}, \mathrm{pH} 7.4$ upon varying the excitation wavelength.

With the formation of $\mathbf{E u}_{2} \mathbf{L T b}$, we sought to investigate the potential of this molecule for detection of anions. Namely, the responsiveness of coordinatively unsaturated cyclen-based Ln(III) chelates to small endogenous anions has previously been addressed by many researchers [35,36]. It is well known that the water molecules directly bound to the $\mathrm{Eu}(\mathrm{III})$ or $\mathrm{Tb}$ (III) ions quench luminescence efficiently due to the high energy of the $\mathrm{O}-\mathrm{H}$ vibrations [37,38]. On the other hand, anions can occupy the apical position by displacing the water molecule and can circumvent the non-radiative energy quenching, giving rise to an increase in the luminescence intensity. We therefore tested whether the trismacrocyclic host $\mathbf{E u}_{2} \mathbf{L T b}$ can interact with selected biologically important anions. Thus, the interactions between $\mathbf{E u}_{2} \mathbf{L T b}$ and anions including $\mathrm{F}^{-}, \mathrm{Br}^{-}, \mathrm{I}^{-}, \mathrm{HCO}_{3}{ }^{-}, \mathrm{HPO}_{4}{ }^{2-}, \mathrm{OAc}^{-}$and 
$\mathrm{SO}_{4}{ }^{2-}$ were assessed, respectively (Figure 4 ). The solutions were excited at $285 \mathrm{~nm}$ in order to cover excitation of both $\mathrm{Eu}(\mathrm{III})$ and $\mathrm{Tb}(\mathrm{III})$, while the emission intensities were monitored in the range between $540 \mathrm{~nm}$ and $630 \mathrm{~nm}$. The results showed no significant change in the emission intensities, except for $\mathrm{HCO}_{3}{ }^{-}$and $\mathrm{OAc}^{-}$(Figure 4). Interestingly, $\mathrm{HCO}_{3}{ }^{-}$led to emission enhancement of Eu(III), while the $\mathrm{OAc}^{-}$enhanced the luminescence of $\mathrm{Tb}(\mathrm{III})$, suggesting that bicarbonates preferentially bind to cyclen-derived chelates, whereas the Tb-18C6 cage dominantly interacts with acetates. Furthermore, anions $\mathrm{F}^{-}$and $\mathrm{HPO}_{4}{ }^{2-}$ slightly quenched the emission of $\mathrm{Tb}$ (III) ion only. It cannot be excluded that the latter is result of the $\mathrm{Tb}$ (III)-phosphate formation and precipitation of this salt, which ultimately reduces the $\mathrm{Tb}(\mathrm{III})$ centered emission intensity due to elimination of this metal ion from the solution.
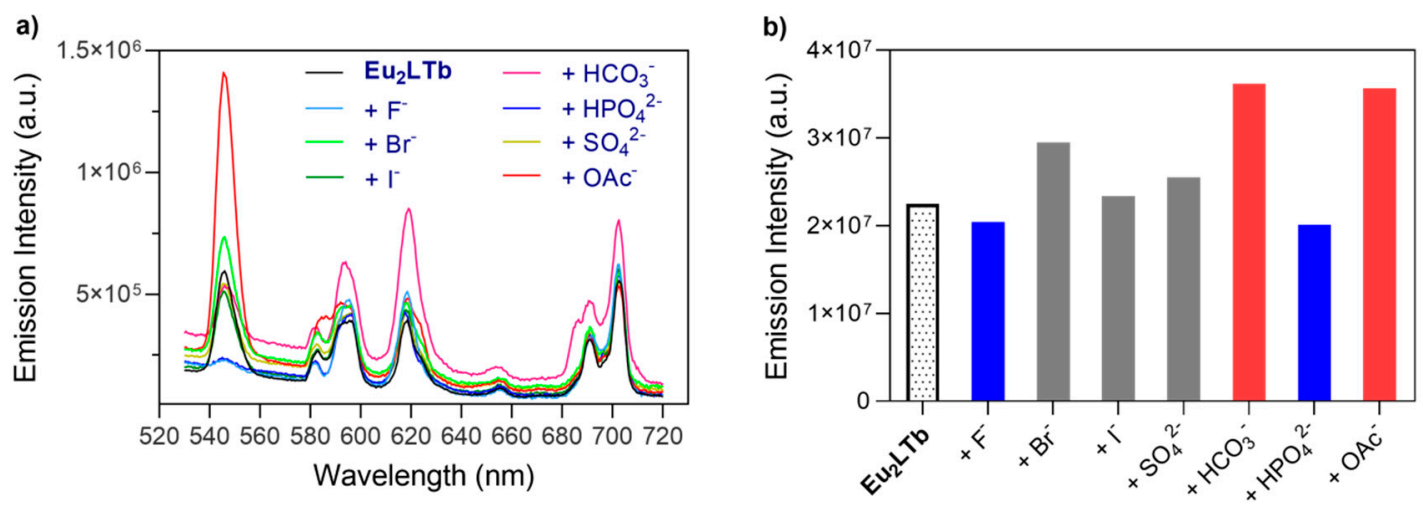

Figure 4. Luminescence selectivity studies of $0.2 \mathrm{mM}$ complex $\mathbf{E u}_{2} \mathbf{L T b}$ at $25^{\circ} \mathrm{C}, \mathrm{pH} 7.4$ with various anions (2.0 equiv.), $\lambda_{\mathrm{ex}}=305 \mathrm{~nm}$. (a) Emission spectra of $\mathbf{E} \mathbf{u}_{2} \mathbf{L T b}$ alone and after addition of $\mathrm{F}^{-}, \mathrm{Br}^{-}, \mathrm{I}^{-}$, $\mathrm{HCO}_{3}{ }^{-}, \mathrm{HPO}_{4}{ }^{2-}, \mathrm{SO}_{4}{ }^{2-}$ and $\mathrm{OAc}^{-}$. (b) Comparison of the recorded luminescence emission intensities monitored in the range between $540 \mathrm{~nm}$ and $630 \mathrm{~nm}$.

\section{Experimental Section}

\subsection{Materials}

Compounds 2 and 5 were synthesized following previously reported procedures [22,24]. All other reagents and solvents were purchased from commercial sources and were used without further purification.

\subsection{General Methods}

Purification of synthesized compounds was performed using silica gel 60 (0.03-0.2 mm) from Carl Roth (Germany). The final ligand and metallated complexes were purified using preparative HPLC on a Varian PrepStar system equipped with the UV-vis detector model 335 and a binary pump model SD-1 manual injector, controlled by Star chromatography workstation version 6.3 software. Low resolution mass spectra were recorded on an ion trap SL 1100 system Agilent with an electrospray ionization source. High resolution mass spectra were recorded on a Bruker Daltonics APEX II (FT-ICR-MS) with an electrospray ionization source.

\subsection{Synthesis}

(2-Bromo-acetylamino)-acetic acid ethyl ester (2). A solution of 2-bromoacetyl bromide (17.4 $\mathrm{g}$, $86.0 \mathrm{mmol})$ in $\mathrm{CH}_{2} \mathrm{Cl}_{2}(20 \mathrm{~mL})$ was added dropwise to a stirred cooled solution $\left(0^{\circ} \mathrm{C}\right)$ of the glycine ethyl ester hydrochloride $(10.1 \mathrm{~g}, 72.0 \mathrm{mmol})$ and $\mathrm{K}_{2} \mathrm{CO}_{3}(29.9 \mathrm{~g}, 216.0 \mathrm{mmol})$ in a mixture of $\mathrm{CH}_{2} \mathrm{Cl}_{2}$ $(100 \mathrm{~mL})$ and water $(50 \mathrm{~mL})$. The resulting solution was warmed to room temperature and stirred for $16 \mathrm{~h}$, after which the organic layer was washed with water $(2 \times 60 \mathrm{~mL})$ and brine $(1 \times 60 \mathrm{~mL})$, dried over anhydrous $\mathrm{Na}_{2} \mathrm{SO}_{4}$, and concentrated in vacuo. The crude product was recrystallized from EtOAc to afford 2 (12.9 g, 80\%) as white crystals [24]. ${ }^{1} \mathrm{H}-\mathrm{NMR}\left(\mathrm{CDCl}_{3}, 300 \mathrm{MHz}\right): \delta(\mathrm{ppm}) 1.16-1.47$ (m, 3H, 
$\left.\mathrm{CH}_{3}\right) ; 3.93\left(\mathrm{~s}, 2 \mathrm{H}, \mathrm{BrCH}_{2}\right) ; 4.06,4.07\left(\mathrm{~d}, J=5.20 \mathrm{~Hz}, 2 \mathrm{H}, \mathrm{NHCH}_{2}\right) ; 4.20,4.23,4.25,4.28(\mathrm{q}, J=7.18 \mathrm{~Hz}, 2 \mathrm{H}$, $\left.\mathrm{OCH}_{2}\right) .{ }^{13} \mathrm{C}-\mathrm{NMR}\left(\mathrm{CDCl}_{3}, 75 \mathrm{MHz}\right): \delta(\mathrm{ppm}) 13.9\left(\mathrm{CH}_{3}\right) ; 32.0\left(\mathrm{BrCH}_{2}\right) ; 42.0\left(\mathrm{NHCH}_{2}\right) ; 61.7\left(\mathrm{OCH}_{2} \mathrm{CH}_{3}\right)$; $168.7(\mathrm{CONH}) ; 170.4(\mathrm{COO})$.

$\{4,7,10$-Tris-[(ethoxycarbonylmethyl-carbamoyl)-methyl]-1,4,7,10tetraaza-cyclododec-1-yl\}-acetic acid benzyl ester (3). The mixture of cyclen-monoacetate benzyl ester $\mathbf{1}\left(3.2 \mathrm{~g}, 10.0 \mathrm{mmol}\right.$ ) and $\mathrm{Na}_{2} \mathrm{CO}_{3}$ $(4.2 \mathrm{~g}, 40.0 \mathrm{mmol})$ were stirred in $\mathrm{CH}_{2} \mathrm{Cl}_{2}(35 \mathrm{~mL})$ at room temperature for $10 \mathrm{~min}$, then compound 2 in $\mathrm{CH}_{2} \mathrm{Cl}_{2}(9.0 \mathrm{~g}, 40.0 \mathrm{mmol}$ in $15 \mathrm{~mL})$ was added dropwise. The reaction mixture was stirred at room temperature for $12 \mathrm{~h}$. Upon reaction completion, the reaction mixture was filtered off, the filtrate was evaporated, and the solid residue was purified by silica column chromatography using $\mathrm{CH}_{2} \mathrm{Cl}_{2} / \mathrm{MeOH}$ $(v / v, 20: 1)$ as the eluent to yield $2(3.8 \mathrm{~g}, 50 \%)$ as a yellow oil. ${ }^{1} \mathrm{H}-\mathrm{NMR}\left(\mathrm{CDCl}_{3}, 300 \mathrm{MHz}\right): \delta(\mathrm{ppm})$ : 1.14-1.31 (m, 9H, $\left.\mathrm{CH}_{3}\right) ; 2.16-2.90\left(\mathrm{br}, 16 \mathrm{H}, \mathrm{NCH}_{2} \mathrm{CH}_{2}\right)$; 3.05-3.54 (br, 8H, NCH $\left.2 \mathrm{CO}\right) ; 3.87-4.26$ (br, $12 \mathrm{H}$, $\left.\mathrm{NHCH}_{2} \mathrm{C}, \mathrm{OCH}_{2} \mathrm{CH}_{3}\right) ; 5.14\left(\mathrm{~s}, 2 \mathrm{H}, \mathrm{ArCH}_{2} \mathrm{O}\right) ; 7.28-7.46(\mathrm{~m}, 5 \mathrm{H}, \mathrm{ArH}) .{ }^{13} \mathrm{C}-\mathrm{NMR}\left(\mathrm{CDCl}_{3}, 75 \mathrm{MHz}\right)$ : $\delta$ (ppm): $14.3\left(\mathrm{CH}_{3}\right) ; 41.0,41.1,41.3\left(\mathrm{NHCH}_{2}\right) ; 50.6,55.6,57.2,57.5,58.3\left(\mathrm{NCH}_{2}\right) ; 61.4\left(\mathrm{OCH}_{2} \mathrm{CH}_{3}\right)$; $67.0\left(\mathrm{ArCH}_{2}\right) ; 128.5,128.8(\mathrm{ArCH}) ; 135.5\left(\mathrm{ArCCH}_{2}\right) ; 170.0,170.2(\mathrm{CONH}) ; 172.5,172.8(\mathrm{COO})$; ESI-HRMS: $(m / z)[\mathrm{M}+\mathrm{H}]^{+}$calcd for $\mathrm{C}_{35} \mathrm{H}_{56} \mathrm{~N}_{7} \mathrm{O}_{11}{ }^{+}, 750.4032$; found: 750.4031 .

$\{4,7,10$-Tris-[(ethoxycarbonylmethyl-carbamoyl)-methyl]-1,4,7,10tetraaza-cyclododec-1-yl\}-acetic acid (4). The compound $3(2.0 \mathrm{~g}, 2.7 \mathrm{mmol})$ was dissolved in DMF $(25 \mathrm{~mL})$. The catalyst $\mathrm{Pd} / \mathrm{C}(10 \%$, $w / w, 0.2$ equiv) and $10 \mu \mathrm{L}$ of ammonia in $\mathrm{MeOH}(7 \mathrm{M})$ were added. The mixture solution was shaken in Parr apparatus in the atmosphere of $\mathrm{H}_{2}$ (3.2 bar) for $12 \mathrm{~h}$ at room temperature. The resulting solution was filtered off and concentrated in vacuo to afford $4(1.6 \mathrm{~g}, 90 \%)$ as a brown oil. ${ }^{1} \mathrm{H}-\mathrm{NMR}$ $\left(\mathrm{CDCl}_{3}, 300 \mathrm{MHz}\right): \delta(\mathrm{ppm}): 1.14-1.36\left(\mathrm{br}, 9 \mathrm{H}, \mathrm{CH}_{3}\right) ; 2.14-3.78\left(\mathrm{br}, 24 \mathrm{H}, \mathrm{NCH}_{2}\right) ; 3.79-4.26(\mathrm{br}, 12 \mathrm{H}$, $\left.\mathrm{NHCH}_{2}, \mathrm{OCH}_{2}\right) .{ }^{13} \mathrm{C}-\mathrm{NMR}\left(\mathrm{CDCl}_{3}, 75 \mathrm{MHz}\right): \delta(\mathrm{ppm}): 14.1\left(\mathrm{CH}_{3}\right) ; 41.2\left(\mathrm{NHCH}_{2}\right) ; 49.9,50.5,57.6$, 57.7 $\left(\mathrm{NCH}_{2}\right) ; 61.4\left(\mathrm{OCH}_{2} \mathrm{CH}_{3}\right) ; 170.0,170.1(\mathrm{CONH}) ; 172.1(\mathrm{COO})$; ESI-HRMS: $(\mathrm{m} / \mathrm{z})[\mathrm{M}+\mathrm{H}]^{+}$calcd for $\mathrm{C}_{28} \mathrm{H}_{50} \mathrm{~N}_{7} \mathrm{O}_{11}{ }^{+}$, 660.3563; found: 660.3559 .

(2-Bromo-ethyl)-carbamic acid benzyl ester (5). To a mixture of 2-bromoethylamine hydrogen bromide $(2.0 \mathrm{~g}, 10.0 \mathrm{mmol})$ and triethylamine $\mathrm{Et}_{3} \mathrm{~N}(3.0 \mathrm{~g}, 30.0 \mathrm{mmol})$ in $\mathrm{CH}_{2} \mathrm{Cl}_{2}(40 \mathrm{~mL})$, benzyl chloroformate $(2.7 \mathrm{~g}, 16.0 \mathrm{mmol})$ was added in a portion-wise manner at $0{ }^{\circ} \mathrm{C}$. The resulting mixture was stirred at $0{ }^{\circ} \mathrm{C}$ for $6 \mathrm{~h}$. The mixture was then washed with aqueous $\mathrm{NaHCO}_{3}(10 \%$, $3 \times 10 \mathrm{~mL})$ and citric acid $(10 \%, 3 \times 10 \mathrm{~mL})$ and dried over anhydrous $\mathrm{Na}_{2} \mathrm{SO}_{4}$. The solvent was then evaporated to obtain crude residue, which was purified by column chromatography (silica gel, hexane/EtOAc, 7:1) to afford $5(2.3 \mathrm{~g}, 90 \%$ yield $)$ as a white crystal solid [22]. ${ }^{1} \mathrm{H}-\mathrm{NMR}\left(\mathrm{CDCl}_{3}\right.$, $300 \mathrm{MHz}): \delta(\mathrm{ppm}): 3.01-3.56\left(\mathrm{~m}, 4 \mathrm{H}, \mathrm{BrCH}_{2}, \mathrm{CH}_{2} \mathrm{NH}\right) ; 5.04\left(\mathrm{~s}, 2 \mathrm{H}, \mathrm{ArCH}_{2}\right) ; 7.21-7.36(\mathrm{br}, 5 \mathrm{H}$, $\mathrm{ArH}) .{ }^{13} \mathrm{C}-\mathrm{NMR}\left(\mathrm{CDCl}_{3}, 75 \mathrm{MHz}\right): \delta(\mathrm{ppm}): 31.8\left(\mathrm{BrCH}_{2}\right) ; 42.4\left(\mathrm{CH}_{2} \mathrm{NH}\right) ; 66.5\left(\mathrm{ArCH}_{2}\right) ; 126.6,127.7$, $128.2(\mathrm{ArCH}) ; 136.0\left(\mathrm{ArCCH}_{2}\right) ; 155.3(\mathrm{CONH})$.

\{2-[16-(2-Benzyloxycarbonylamino-ethyl)-1,4,10,13-tetraoxa-7,16-diaza-cyclooctadec-7-yl]-ethyl\}carbamic acid benzyl ester (6). $\mathrm{Cs}_{2} \mathrm{CO}_{3}(3.9 \mathrm{~g}, 12.0 \mathrm{mmol})$ was added to a solution of 1,10-diaza-18-crown-6 (0.8 g, $3.0 \mathrm{mmol})$ in dry MeCN $(15 \mathrm{~mL})$. The obtained suspension was stirred for $10 \mathrm{~min}$ at room temperature and then $5(1.7 \mathrm{~g}, 6.6 \mathrm{mmol})$ was added to it. The mixture was heated to $65^{\circ} \mathrm{C}$ and stirred for $1.5 \mathrm{~h}$ after which additional amount of 5 ( $\left.0.8 \mathrm{~g}, 3.1 \mathrm{mmol}\right)$ was added and the reaction mixture was stirred for $3 \mathrm{~h}$. Afterwards, the solvent was evaporated under the reduced pressure and the crude was purified by column chromatography (silica gel, $\mathrm{CH}_{2} \mathrm{Cl}_{2} / \mathrm{MeOH}$, 100:7) to give $6(1.6 \mathrm{~g}, 58 \%)$ as a brown oil. ${ }^{1} \mathrm{H}-\mathrm{NMR}\left(\mathrm{CDCl}_{3}, 300 \mathrm{MHz}\right): \delta(\mathrm{ppm}): 2.43-2.98(\mathrm{br}, 12 \mathrm{H}$, $\mathrm{NCH}_{2} \mathrm{CH}_{2}$ ); 3.17-3.39 (br, $\left.4 \mathrm{H}, \mathrm{CH}_{2} \mathrm{CH}_{2} \mathrm{NH}\right)$; 3.47-3.64 (br, $\left.16 \mathrm{H}, \mathrm{CH}_{2} \mathrm{OCH}_{2}\right) ; 5.08$ (s, 2H, $\mathrm{ArCH}_{2}$ ); 7.21-7.45 (br, $10 \mathrm{H}, \mathrm{ArH}) .{ }^{13} \mathrm{C}-\mathrm{NMR}\left(\mathrm{CDCl}_{3}, 75 \mathrm{MHz}\right): \delta$ (ppm): $38.9\left(\mathrm{CH}_{2} \mathrm{NH}\right) ; 53.5\left(\mathrm{NCH}_{2} \mathrm{CH}_{2}\right)$; $66.3\left(\mathrm{ArCH}_{2}\right) ; 67.6,68.7\left(\mathrm{CH}_{2} \mathrm{OCH}_{2}\right) ; 127.8,128.2,128.5(\mathrm{ArCH}) ; 136.6\left(\mathrm{ArCCH}_{2}\right) ; 156.9(\mathrm{CONH})$. ESI-HRMS: $(m / z)[\mathrm{M}+\mathrm{Na}]^{+}$calcd for $\mathrm{C}_{32} \mathrm{H}_{48} \mathrm{~N}_{4} \mathrm{NaO}_{8}{ }^{+}, 639.3364$; found: 639.3376 .

2-[16-(2-Amino-ethyl)-1,4,10,13-tetraoxa-7,16-diaza-cyclooctadec-7-yl]-ethylamine (7). The compound $6(1.2 \mathrm{~g}, 1.9 \mathrm{mmol})$ was dissolved in $\mathrm{EtOH}(25 \mathrm{~mL})$. The catalyst $\mathrm{Pd} / \mathrm{C}(10 \% \mathrm{w} / w, 0.2$ equiv. $)$ and $10 \mu \mathrm{L}$ of 
ammonia in $\mathrm{MeOH}(7 \mathrm{M})$ were added. The solution was shaken in Parr apparatus in the atmosphere of $\mathrm{H}_{2}$ (3.2 bar) for $4 \mathrm{~h}$ at room temperature. Removal of the catalyst by filtration and evaporation of EtOH yielded the diamine $7(0.6 \mathrm{~g}, 88 \%) .{ }^{1} \mathrm{H}-\mathrm{NMR}\left(\mathrm{D}_{2} \mathrm{O}, 300 \mathrm{MHz}\right): \delta(\mathrm{ppm}): 2.68-2.94\left(\mathrm{br}, 12 \mathrm{H}, \mathrm{NCH}_{2} \mathrm{CH}_{2}\right)$; 3.28-3.33 (br, 4H, $\left.\mathrm{CH}_{2} \mathrm{CH}_{2} \mathrm{NH}_{2}\right)$; 3.48-3.81 (br, $\left.16 \mathrm{H}, \mathrm{CH}_{2} \mathrm{OCH}_{2}\right) .{ }^{13} \mathrm{C}-\mathrm{NMR}\left(\mathrm{D}_{2} \mathrm{O}, 75 \mathrm{MHz}\right): \delta(\mathrm{ppm})$ : $36.9\left(\mathrm{CH}_{2} \mathrm{NH}_{2}\right) ; 51.8,53.9\left(\mathrm{NCH}_{2} \mathrm{CH}_{2}\right) ; 68.2,69.7\left(\mathrm{CH}_{2} \mathrm{OCH}_{2}\right)$. ESI-HRMS: $(\mathrm{m} / \mathrm{z})[\mathrm{M}+\mathrm{H}]^{+}$calcd for $\mathrm{C}_{16} \mathrm{H}_{37} \mathrm{~N}_{4} \mathrm{O}_{4}{ }^{+}$, 349.2809; found: 349.2816 .

Compound 8. The acid $4(1.1 \mathrm{~g}, 1.7 \mathrm{mmol})$ and HATU (1-[Bis(dimethylamino)methylene]-1H-1,2,3triazolo[4,5-b]pyridinium 3-oxide hexafluorophosphate, Hexafluorophosphate Azabenzotriazole Tetramethyl Uronium, $0.7 \mathrm{~g}, 1.9 \mathrm{mmol}$ ) were subsequently added to a stirred solution of diamine $7(0.2 \mathrm{~g}, 0.6 \mathrm{mmol})$ in dry DMF $(10 \mathrm{~mL})$, after which the reaction mixture was stirred for $6 \mathrm{~h}$ at room temperature. The solvent was removed under the reduced pressure and the residue was washed with $\mathrm{Et}_{2} \mathrm{O}(3 \times 10 \mathrm{~mL}), \mathrm{CH}_{2} \mathrm{Cl}_{2}(3 \times 10 \mathrm{~mL})$ and $\mathrm{MeOH}(2 \times 10 \mathrm{~mL})$. The collected filtrate was concentrated in vacuo to give a yellowish oil $(0.4 \mathrm{~g}, 48 \%)$. ${ }^{1} \mathrm{H}-\mathrm{NMR}\left(\mathrm{CD}_{3} \mathrm{OD}, 300 \mathrm{MHz}\right)$ : $\delta$ (ppm): 1.23, 1.25, $1.28\left(\mathrm{t}, J=7.50 \mathrm{~Hz}, 18 \mathrm{H}, \mathrm{CH}_{3}\right) ; 3.39-3.83\left(\mathrm{br}, 64 \mathrm{H}, \mathrm{CH}_{2}\right)$; 3.94-4.05 (br, 16H, OCH 2$)$; 4.05-4.12 (br, 12H, $\left.\mathrm{NHCH}_{2} \mathrm{C}\right) ; 4.14-4.26$ (m, 12H, $\left.\mathrm{NHCH}_{2} \mathrm{CO}\right) .{ }^{13} \mathrm{C}-\mathrm{NMR}\left(\mathrm{CD}_{3} \mathrm{OD}, 75 \mathrm{MHz}\right): \delta(\mathrm{ppm})$ : $14.5\left(\mathrm{CH}_{3}\right) ; 42.2\left(\mathrm{NHCH}_{2}\right) ; 55.2,56.3,62.0,64.7,65.3,70.9\left(\mathrm{NCH}_{2}\right) ; 170.3,(\mathrm{CONH}, \mathrm{COO})$. ESI-HRMS: $(m / z)[\mathrm{M}+3 \mathrm{H}]^{3+}$ calcd for $\mathrm{C}_{72} \mathrm{H}_{133} \mathrm{~N}_{18} \mathrm{O}_{24}{ }^{3+}, 544.6575$; found: 544.6575 .

Compound $\mathbf{H}_{6} \mathbf{L}$. Compound $\mathbf{8}(300 \mathrm{mg}, 0.2 \mathrm{mmol})$ was dissolved in $\mathrm{MeOH}(5 \mathrm{~mL})$ and treated with $\mathrm{LiOH}(130 \mathrm{mg}, 5.5 \mathrm{mmol})$ at room temperature for $12 \mathrm{~h}$. After removal of LiOH by filtration, $\mathrm{MeOH}$ was evaporated. The crude mixture was dissolved in water and the $\mathrm{pH}$ was adjusted to 7 and purified by preparative HPLC. The white powder $\mathbf{H}_{6} \mathbf{L}(120 \mathrm{mg}, 45 \%)$ was obtained by lyophilization. ${ }^{1} \mathrm{H}-\mathrm{NMR}\left(\mathrm{D}_{2} \mathrm{O}, 300 \mathrm{MHz}\right): \delta$ (ppm): 3.04-3.31 (br, 30H, cyclen $\mathrm{NCH}_{2}$ ), 3.33-3.52 (br, $18 \mathrm{H}$, cyclen $\left.\mathrm{NCH}_{2}\right)$, 3.53-3.62 (br, 12H, crown ether $\left.\mathrm{NCH}_{2}\right), 3.63-3.79$ (br, 16H, crown ether $\left.\mathrm{OCH}_{2}\right), 3.80-3.96(\mathrm{br}, 16 \mathrm{H}$, $\left.\mathrm{CONHCH}_{2}\right) .{ }^{13} \mathrm{C}-\mathrm{NMR}\left(\mathrm{D}_{2} \mathrm{O}, 75 \mathrm{MHz}\right): \delta(\mathrm{ppm}): 41.1\left(\mathrm{NHCH}_{2}\right) ; 53.2,54.8,55.1,63.6\left(\mathrm{NCH}_{2}\right)$; $69.7\left(\mathrm{OCH}_{2}\right) ; 162.8,172.8,(\mathrm{CONH}, \mathrm{COOH})$. ESI-HRMS: $(\mathrm{m} / \mathrm{z})[\mathrm{M}-\mathrm{H}]^{-}$calcd for $\mathrm{C}_{60} \mathrm{H}_{105} \mathrm{~N}_{18} \mathrm{O}_{24}{ }^{-}$, 1461.7555; found: 1461.7548 .

Complex $\mathbf{E u}_{2} \mathbf{L}$. The ligand $\mathbf{H}_{6} \mathbf{L}(100 \mathrm{mg}, 0.07 \mathrm{mmol})$ was dissolved in MilliQ water and the $\mathrm{pH}$ value was set to 7 . The aqueous solution of $\mathrm{EuCl}_{3} \cdot 6 \mathrm{H}_{2} \mathrm{O}(55 \mathrm{mg}, 0.15 \mathrm{mmol})$ was added dropwise to the ligand solution. The mixture was heated at $50{ }^{\circ} \mathrm{C}$ for $12 \mathrm{~h}$ and the $\mathrm{pH}$ of the solution was periodically adjusted to 7.0 by addition of $0.1 \mathrm{M} \mathrm{NaOH}$ solution. Then, the reaction mixture was cooled to room temperature and purified by HPLC. The yellow solid compound ( $84 \mathrm{mg}, 70 \%)$ was obtained by lyophilization. ESI-HRMS: $(m / z)[\mathrm{M}+3 \mathrm{H}]^{3+}$ calcd for $\mathrm{C}_{60} \mathrm{H}_{103} \mathrm{Eu}_{2} \mathrm{~N}_{18} \mathrm{O}_{24}{ }^{3+}$, 588.5267; found: 588.5279 .

Complex $\mathbf{E u}_{2} \mathbf{L T b}$. To a stirred solution of $\mathbf{E u}_{2} \mathbf{L}(40 \mathrm{mg}, 0.02 \mathrm{mmol})$ in MilliQ water (pH 7), the aqueous solution of $\mathrm{TbCl}_{3} \cdot 6 \mathrm{H}_{2} \mathrm{O}(10 \mathrm{mg}, 0.03 \mathrm{mmol})$ was added dropwise while maintaining $\mathrm{pH}$ with $0.1 \mathrm{M} \mathrm{NaOH}(\mathrm{aq})$. The reaction mixture was stirred at $50{ }^{\circ} \mathrm{C}$ for $6 \mathrm{~h}$. Then the solvent was reduced under the vacuum and the gray solid powder was obtained upon lyophilization. LC-MS: $(m / z)[\mathrm{M}+\mathrm{H}]^{2+}$ calcd for $\mathrm{C}_{60} \mathrm{H}_{99} \mathrm{Eu}_{2} \mathrm{~N}_{18} \mathrm{O}_{24} \mathrm{~Tb}^{2+}$, 959.3; found: 959.3.

\subsection{NMR Spectroscopy}

${ }^{1} \mathrm{H},{ }^{13} \mathrm{C}-\mathrm{NMR}$ and CEST experiments were recorded on a Bruker Avance III $300 \mathrm{MHz}$ spectrometer. ${ }^{1} \mathrm{H}$ and ${ }^{13} \mathrm{C}-\mathrm{NMR}$ spectra were recorded at $25{ }^{\circ} \mathrm{C}$, using either $\mathrm{CDCl}_{3}$ or $\mathrm{D}_{2} \mathrm{O}$ and referenced to TMS/TSP. Processing was performed using TopSpin 2.1 (Bruker GmbH) and ACD/SpecManager 9.0 (Advanced Chemistry Development, Inc., Toronto, Canada). The concentrations of $\mathbf{E u}_{2} \mathbf{L}$ and $\mathrm{TbCl}_{3}$ were determined using the bulk magnetic susceptibility shift (BMS) method [39]. CEST spectra were obtained in $10 \% \mathrm{D}_{2} \mathrm{O}$ and $90 \% \mathrm{H}_{2} \mathrm{O}$ solutions of the paramagnetic complex, using a saturation time of $10 \mathrm{~s}$ at $7 \mathrm{~T}$ and different temperatures $\left(10,15,20,25,30,35,37\right.$ and $\left.40{ }^{\circ} \mathrm{C}\right)$ and a frequency-offset range of $\pm 100 \mathrm{ppm}$ with $1 \mathrm{ppm}$ resolution. The longitudinal and transverse relaxation times, $T_{1}$ and 
$T_{2}$, were measured using the inversion-recovery and Carr-Purcell-Meiboom-Gill pulse sequences, respectively $[40,41]$.

\subsection{Optical Spectroscopy}

All fluorescence spectra were recorded on a QuantaMaster ${ }^{\mathrm{TM}} 3 \mathrm{PH}$ fluorescence spectrometer from Photon Technology International, Inc. (USA) at $25^{\circ} \mathrm{C}$ and $\mathrm{pH}$ 7.4. Titration experiments with $\mathrm{Tb}(\mathrm{III})$ were performed by following the emission intensity at $545 \mathrm{~nm}$. For the anion selectivity experiments, appropriate concentration $(0.2 \mathrm{mM})$ of $\mathrm{F}^{-}, \mathrm{Br}^{-}, \mathrm{I}^{-}, \mathrm{HCO}_{3}{ }^{-}, \mathrm{SO}_{4}{ }^{2-}, \mathrm{OAc}^{-}$and $\mathrm{HPO}_{4}{ }^{2-}$ were prepared by dilution method using HPLC grade water. All data were recorded in HEPES buffer ( $50 \mathrm{mM}, \mathrm{pH} 7.4$ ), using the excitation wavelength at $305 \mathrm{~nm}$ and the slit widths of $5 \mathrm{~nm}$ and $1 \mathrm{~nm}$ for excitation and emission, respectively.

\section{Conclusions}

A trismacrocyclic DOTA-amide DA18C6-based ligand framework was prepared and characterized. The novel dinuclear $\mathbf{E u}_{\mathbf{2}} \mathbf{L}$ contrast agent showed the paraCEST properties typical to that of well-known EuDOTAM-Gly probe, albeit with greater potential for stronger CEST effect due to its bismacrocyclic and dinuclear nature. Upon introduction of $\mathbf{T b}(\mathrm{III})$ ions, the resulting trinuclear $\mathbf{E u}_{\mathbf{2}} \mathbf{L T} \mathbf{b}$ complex exhibited mixed luminescence emission. Moreover, the binding studies with various anions revealed specificity to $\mathrm{HCO}_{3}{ }^{-}$and $\mathrm{OAc}^{-}$over other biologically relevant anions. The typical paraCEST signal and combined luminescence emission properties pave the way for this class of mixed macrocyclic ligands to develop further as potential dual-modal MRI/luminescence probes.

Supplementary Materials: The supplementary materials are available online. Figure S1: Change in T1 and T2

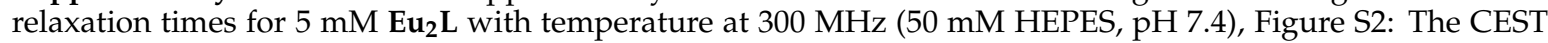

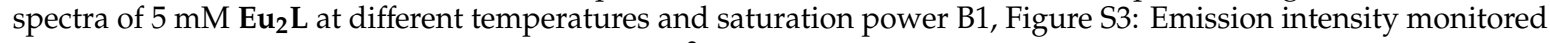
at $545 \mathrm{~nm}$ of $0.2 \mathrm{mM} \mathrm{Eu}_{2} \mathrm{~L}$ upon titration with $\mathrm{Tb}^{3+}$ at $25^{\circ} \mathrm{C}(50 \mathrm{mM}$ HEPES, pH 7.4).

Author Contributions: G.W. and G.A. contributed the conceptualization and methodology. G.W. prepared the complexes and performed the measurements. G.W. and G.A. analyzed and interpreted the results, then allocated and wrote the manuscript. Both authors have read and agreed to the published version of the manuscript.

Funding: G.W. was supported by the China Scholarship Council (CSC, PhD fellowship).

Acknowledgments: The authors acknowledge the support of the China Scholarship Council (CSC, PhD fellowship).

Conflicts of Interest: The authors declare no conflict of interest.

\section{References}

1. Edelman, R.R.; Hesselink, J.R.; Zlatkin, M.B. MRI: Clinical Magnetic Resonance Imaging, 2nd ed.; W. B. Saunders Company: Philadelphia, PA, USA, 1996; Volume 2.

2. Zhang, K.; Cheng, Y.; Ren, W.W.; Sun, L.P.; Liu, C.; Wang, D.; Guo, L.H.; Xu, H.X.; Zhao, Y.X. Coordination-Responsive Longitudinal Relaxation Tuning as a Versatile MRI Sensing Protocol for Malignancy Targets. Adv. Sci. 2018, 5, 1800021. [CrossRef] [PubMed]

3. Helm, L.; Merbach, A.E.; Tóth, E.V. The Chemistry of Contrast Agents in Medical Magnetic Resonance Imaging, 2nd ed.; John Wiley \& Sons Inc.: Hoboken, NJ, USA, 2013; p. 496.

4. Ward, K.M.; Aletras, A.H.; Balaban, R.S. A new class of contrast agents for MRI based on proton chemical exchange dependent saturation transfer (CEST). J. Magn. Reson. 2000, 143, 79-87. [CrossRef] [PubMed]

5. Wahsner, J.; Gale, E.M.; Rodriguez-Rodriguez, A.; Caravan, P. Chemistry of MRI Contrast Agents: Current Challenges and New Frontiers. Chem. Rev. 2019, 119, 957-1057. [CrossRef] [PubMed]

6. Evbuomwan, O.M.; Terreno, E.; Aime, S.; Sherry, A.D. CEST and PARACEST Agents for Molecular Imaging. In The Chemistry of Molecular Imaging; Long, N., Wong, W.T., Eds.; John Wiley \& Sons: Hoboken, NJ, USA, 2014; pp. 224-243.

7. Zhang, S.R.; Merritt, M.; Woessner, D.E.; Lenkinski, R.E.; Sherry, A.D. PARACEST agents: Modulating MRI contrast via water proton exchange. Acc. Chem. Res. 2003, 36, 783-790. [CrossRef] [PubMed] 
8. Heffern, M.C.; Matosziuk, L.M.; Meade, T.J. Lanthanide probes for bioresponsive imaging. Chem. Rev. 2014, 114, 4496-4539. [CrossRef]

9. Rodríguez-Rodríguez, A.; Zaiss, M.; Esteban-Gómez, D.; Angelovski, G.; Platas-Iglesias, C. Paramagnetic chemical exchange saturation transfer agents and their perspectives for application inmagnetic resonance imaging. Int. Rev. Phys. Chem. 2020, 40, 51-79.

10. Baranyai, Z.; Brucher, E.; Ivanyi, T.; Kiraly, R.; Lazar, I.; Zekany, L. Complexation Properties of $N, N^{\prime}, N^{\prime \prime}, N^{\prime \prime \prime}$-[1,4,7,10-tetraazacyclododecane-1,4,7,10-tetrayltetrakis(1-oxoethane-2,1-diyl)]tetrakis[glycine] $\left(\mathrm{H}_{4}\right.$ dotagl). Equilibrium, Kinetic, and Relaxation Behavior of the Lanthanide(III) Complexes. Helv. Chim. Acta 2005, 88, 604-617. [CrossRef]

11. Sherry, A.D.; Caravan, P.; Lenkinski, R.E. Primer on Gadolinium Chemistry. J. Magn. Reson. Imaging 2009, 30, 1240-1248. [CrossRef]

12. Tircso, G.; Benyo, E.T.; Garda, Z.; Singh, J.; Trokowski, R.; Brucher, E.; Sherry, A.D.; Toth, E.; Kovacs, Z. Comparison of the equilibrium, kinetic and water exchange properties of some metal ion-DOTA and DOTA-bis(amide) complexes. J. Inorg. Biochem. 2020, 206, 111042-111054. [CrossRef]

13. Bunzli, J.C. Lanthanide luminescence for biomedical analyses and imaging. Chem. Rev. 2010, 110, $2729-2755$. [CrossRef]

14. Binnemans, K. Interpretation of europium(III) spectra. Coord. Chem. Rev. 2015, 295, 1-45. [CrossRef]

15. Mamedov, I.; Parac-Vogt, T.N.; Logothetis, N.K.; Angelovski, G. Synthesis and characterization of dinuclear heterometallic lanthanide complexes exhibiting MRI and luminescence response. Dalton Trans. 2010, 39, 5721-5727. [CrossRef]

16. Jones, J.E.; Amoroso, A.J.; Dorin, I.M.; Parigi, G.; Ward, B.D.; Buurma, N.J.; Pope, S.J.A. Bimodal, dimetallic lanthanide complexes that bind to DNA: The nature of binding and its influence on water relaxivity. Chem. Commun. 2011, 47, 3374-3376. [CrossRef] [PubMed]

17. Terreno, E.; Boffa, C.; Menchise, V.; Fedeli, F.; Carrera, C.; Delli Castelli, D.; Digilio, G.; Aime, S. Gadolinium-doped LipoCEST agents: A potential novel class of dual ${ }^{1} \mathrm{H}-\mathrm{MRI}$ probes. Chem. Commun. 2011, 47, 4667-4669. [CrossRef]

18. Debroye, E.; Parac-Vogt, T.N. Towards polymetallic lanthanide complexes as dual contrast agents for magnetic resonance and optical imaging. Chem. Soc. Rev. 2014, 43, 8178-8192. [CrossRef]

19. Placidi, M.P.; Villaraza, A.J.; Natrajan, L.S.; Sykes, D.; Kenwright, A.M.; Faulkner, S. Synthesis and spectroscopic studies on azo-dye derivatives of polymetallic lanthanide complexes: Using diazotization to link metal complexes together. J. Am. Chem. Soc. 2009, 131, 9916-9917. [CrossRef]

20. Sorensen, T.J.; Tropiano, M.; Blackburn, O.A.; Tilney, J.A.; Kenwright, A.M.; Faulkner, S. Preparation and study of an $\mathrm{f}, \mathrm{f}, \mathrm{f}^{\prime}, \mathrm{f}^{\prime \prime}$ covalently linked tetranuclear hetero-trimetallic complex-A europium, terbium, dysprosium triad. Chem. Commun. 2013, 49, 783-785. [CrossRef]

21. Faulkner, S.; Pope, S.J. Lanthanide-sensitized lanthanide luminescence: Terbium-sensitized ytterbium luminescence in a trinuclear complex. J. Am. Chem. Soc. 2003, 125, 10526-10527. [CrossRef]

22. Tseng, M.C.; Chu, Y.H. Chemoselective gas sensing ionic liquids. Chem. Commun. 2010, 46, $2983-2985$. [CrossRef] [PubMed]

23. Zhang, S.; Winter, P.; Wu, K.; Sherry, A.D. A novel europium(III)-based MRI contrast agent. J. Am. Chem. Soc. 2001, 123, 1517-1518. [CrossRef] [PubMed]

24. Evbuomwan, O.M.; Kiefer, G.; Sherry, A.D. Amphiphilic EuDOTA-tetraamide complexes form micelles with enhanced CEST sensitivity. Eur. J. Inorg. Chem. 2012, 2012, 2126-2134. [CrossRef]

25. Cakic, N.; Verbic, T.Z.; Jelic, R.M.; Platas-Iglesias, C.; Angelovski, G. Synthesis and characterisation of bismacrocyclic DO3A-amide derivatives-An approach towards metal-responsive PARACEST agents. Dalton Trans. 2016, 45, 6555-6565. [CrossRef] [PubMed]

26. van Zijl, P.C.M.; Yadav, N.N. Chemical Exchange Saturation Transfer (CEST): What is in a Name and What Isn't? Magn. Reson. Med. 2011, 65, 927-948. [CrossRef] [PubMed]

27. Zhang, S.; Malloy, C.R.; Sherry, A.D. MRI thermometry based on PARACEST agents. J. Am. Chem. Soc. 2005, 127, 17572-17573. [CrossRef] [PubMed]

28. Zaiss, M.; Angelovski, G.; Demetriou, E.; McMahon, M.T.; Golay, X.; Scheffler, K. QUESP and QUEST revisited-Fast and accurate quantitative CEST experiments. Magn. Reson. Med. 2018, 79, 1708-1721. [CrossRef] 
29. Dixon, W.T.; Ren, J.; Lubag, A.J.; Ratnakar, J.; Vinogradov, E.; Hancu, I.; Lenkinski, R.E.; Sherry, A.D. A concentration-independent method to measure exchange rates in PARACEST agents. Magn. Reson. Med. 2010, 63, 625-632. [CrossRef]

30. Suarez, S.; Mamula, O.; Scopelliti, R.; Donnio, B.; Guillon, D.; Terazzi, E.; Piguet, C.; Bunzli, J.C.G. Lanthanide luminescent mesomorphic complexes with macrocycles derived from diaza-18-crown-6. New J. Chem. 2005, 29, 1323-1334. [CrossRef]

31. Sazonov, P.K.; Stolyarenko, V.Y.; Shtern, M.M.; Beletskaya, I.P. Unexpected lanthanide cation selectivity of bis- $\beta$-ketovinylated diaza-18-crown- 6 and open-chain diamines: Cooperative effect of the second keto group. J. Inclusion Phenom. Macrocyclic Chem. 2014, 79, 193-203. [CrossRef]

32. Gao, C.J.; Kirillov, A.M.; Dou, W.; Tang, X.L.; Liu, L.L.; Yan, X.H.; Xie, Y.J.; Zang, P.X.; Liu, W.S.; Tang, Y. Self-Assembly Synthesis, Structural Features, and Photophysical Properties of Dilanthanide Complexes Derived from a Novel Amide Type Ligand: Energy Transfer from $\mathrm{Tb}$ (III) to Eu(III) in a Heterodinuclear Derivative. Inorg. Chem. 2014, 53, 935-942. [CrossRef]

33. Zhang, H.X.; Chen, Z.H.; Liu, X.; Zhang, F. A mini-review on recent progress of new sensitizers for luminescence of lanthanide doped nanomaterials. Nano Res. 2020, 13, 1795-1809. [CrossRef]

34. Kaczmarek, M. Lanthanide-sensitized luminescence and chemiluminescence in the systems containing most often used medicines; a review. J. Lumin. 2020, 222, 117174. [CrossRef]

35. Parker, D.; Dickins, R.S.; Puschmann, H.; Crossland, C.; Howard, J.A. Being excited by lanthanide coordination complexes: Aqua species, chirality, excited-state chemistry, and exchange dynamics. Chem. Rev. 2002, 102, 1977-2010. [CrossRef] [PubMed]

36. Aletti, A.B.; Gillen, D.M.; Gunnlaugsson, T. Luminescent/colorimetric probes and (chemo-) sensors for detecting anions based on transition and lanthanide ion receptor/binding complexes. Coord. Chem. Rev. 2018, 354, 98-120. [CrossRef]

37. Kropp, J.L.; Windsor, M.W. Luminescence and Energy Transfer in Solutions of Rare Earth Complexes. II. Studies of Solvation Shell in Europium(III) and Terbium(III) as a Function of Acetate Concentration. J. Phys. Chem. 1967, 71, 477-482. [CrossRef]

38. Horrocks, W.D.; Sudnick, D.R. Lanthanide Ion Probes of Structure in Biology-Laser-Induced Luminescence Decay Constants Provide a Direct Measure of the Number of Metal-Coordinated Water-Molecules. J. Am. Chem. Soc. 1979, 101, 334-340. [CrossRef]

39. Corsi, D.M.; Platas-Iglesias, C.; van Bekkum, H.; Peters, J.A. Determination of paramagnetic lanthanide(III) concentrations from bulk magnetic susceptibility shifts in NMR spectra. Magn. Reson. Chem. 2001, 39, 723-726. [CrossRef]

40. Meiboom, S.; Gill, D. Modified Spin-Echo Method for Measuring Nuclear Relaxation Times. Rev. Sci. Instrum. 1958, 29, 688-691. [CrossRef]

41. Carr, H.Y.; Purcell, E.M. Effects of Diffusion on Free Precession in Nuclear Magnetic Resonance Experiments. Phys. Rev. 1954, 94, 630-638. [CrossRef]

Sample Availability: Samples of the compounds are not available from the authors.

Publisher's Note: MDPI stays neutral with regard to jurisdictional claims in published maps and institutional affiliations.

(C) 2020 by the authors. Licensee MDPI, Basel, Switzerland. This article is an open access article distributed under the terms and conditions of the Creative Commons Attribution (CC BY) license (http://creativecommons.org/licenses/by/4.0/). 